\title{
New bathymetric record for the fish bighead mora, Laemonema verecundum (Gadiformes: Moridae) in the Gulf of California, Mexico
}

\author{
Nuevo registro batimétrico para el pez carbonero cabezón Laemonema verecundum (Gadiformes: Moridae) en el Golfo de \\ California, México
}

\author{
Rufino Morales-Azpeitia', Juana López-Martínez¹ and José Eduardo Valdez-Holguín² \\ ${ }^{1}$ Centro de Investigaciones Biológicas del Noroeste S.C., Unidad Sonora, Campus Guaymas. Km 2.35 Carretera a las Tinajas S/N, Colonia Tinajas, Guaymas, \\ Sonora 85454. México \\ 2Departamento de Investigaciones Científicas y Tecnológicas de la Universidad de Sonora (DICTUS). Luis Donaldo Colosio s/n, \\ entre Sahuaripa y Reforma, Colonia Centro, Hermosillo, Sonora, 83000. México \\ Aceptado: 29 de agosto de 2016. \\ e-mail:mmorales04@cibnor.mx
}

Recibido: 10 de diciembre de 2015.

Morales-Azpeitia R., J. López-Martínez and J. E. Valdez-Holguín. 2017. New bathymetric record for the fish bighead mora, Laemonema verecundum (Gadiformes: Moridae) in the Gulf of California, Mexico. Hidrobiológica 27(1): 123-126. D0l: 10.24275/uam/izt/dcbs/hidro/2017v27n1/Morales

\section{ABSTRACT}

Background. The presence of Laemonema verecundum (Jordan \& Cramer, 1897) had not been previously reported at depths less than 666 $\mathrm{m}$. Goals. The objective of the research was to study the bathymetric distribution of $L$. verecundum. Methods. In the eastern continental shelf of the Gulf of California, 648 specimens of $L$. verecundum were collected during two experimental research cruises in September 2004 and February 2005. Results. Specimens were collected at depths between 165 and $483 \mathrm{~m}$, where temperatures ranged between 9.5 and $19.9^{\circ}$ $\mathrm{C}$, and average oxygen concentration was $1.7 \mathrm{mg} / \mathrm{l}$. Conclusions. This new record expands the known bathymetric distribution range of this species inhabiting shallow waters in the gulf.

Key words: Depth, distribution, Eastern Central Pacific, Laemonema verecundum, Mexico.

\section{RESUMEN}

Antecedentes. La presencia de Laemonema verecundum (Jordan \& Cramer, 1897) no había sido reportada a profundidades menores de $666 \mathrm{~m}$. Objetivos. El objetivo de esta investigación fue estudiar la distribución batimétrica de $L$. verecundum. Métodos. Se recolectaron 648 ejemplares de $L$. verecundum del talud continental oriental del Golfo de California, durante dos cruceros de investigación realizados en septiembre de 2004 y febrero de 2005. Resultados. Los organismos fueron colectados en un rango de profundidad de 165 a $483 \mathrm{~m}$, donde la temperatura varió de 9.5 a $19.9{ }^{\circ} \mathrm{C}$ y la concentración de oxígeno disuelto promedio fue de $1.7 \mathrm{mg} / \mathrm{l}$. Conclusiones. Este nuevo registro extiende el intervalo de distribución batimétrica de esta especie, habitando aguas menos profundas del golfo.

Palabras clave: Distribución, Laemonema verecundum, México, Pacífico oriental central, profundidad.

The bighead mora Laemonema verecundum (Jordan \& Cramer, 1897) is a relatively poorly-known species belonging to the order Gadiformes, family Moridae. This family currently has 111 species, 17 of which belong to the genus Laemonema (Paulin, 1995). L. verecundum is an oviparous species with planktonic larvae and to date has a maximum recorded size of $11 \mathrm{~cm}$ (Paulin, 1995). It is mesopelagic and endemic to the Eastern Central Pacific with a distribution from $28^{\circ} \mathrm{N}$ to $14^{\circ}$ N (Inada, 1995; Ambrose, 1996). Previous studies have reported the species in marine waters off Sinaloa and Jalisco, Mexico (Inada, 1995; Ambrose, 1996) and in the outer shelf and continental slope of the Gulf of California (Castro-Aguirre \& Balart, 1996).

López-Martínez et al. (2012) have recently mentioned that the species is relatively abundant in the Gulf of California. However, a record of bathymetric distribution had only been found in deep waters from 666 to $2600 \mathrm{~m}$ (Bogutskaya, 2007) where hypoxia and anoxic conditions have prevailed (Hendrickx, 2001; Allen, 2008). Until now, the presence of bighead mora had not been reported at depths less than $666 \mathrm{~m}$ (Robertson \& Allen, 2002).

The specimens $(\mathrm{N}=648)$ of $L$. verecundum were captured during two research cruises onboard the BIP XII vessel in the Gulf of California in September 2004 and February 2005 (Fig. 1). Trawls were carried out at depths of 85-251, 252-419, 420-585, and 587-752 m, with a bottom trawl net of 96.5/86.4 cm length, head rope of $38 \mathrm{~m}$, mesh size of 2.54 


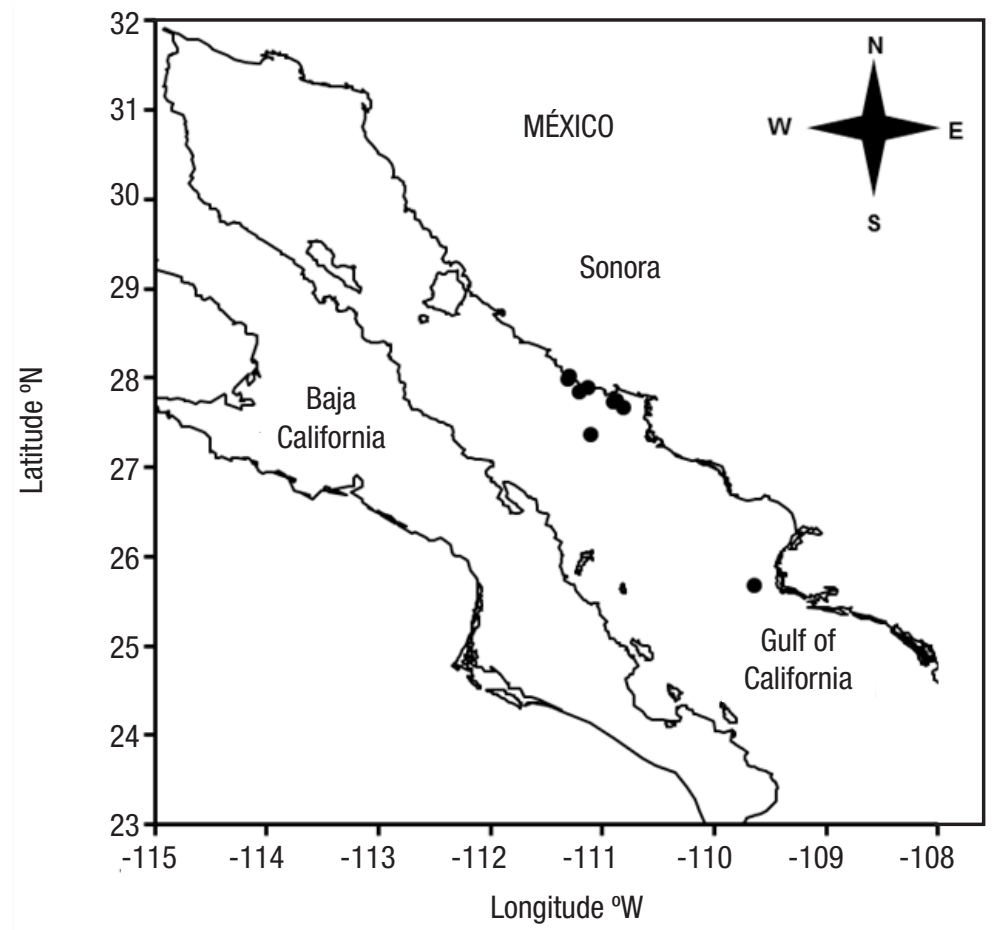

Figure 1. Study area of Laemonema verecundum during the exploration cruises in the Gulf of California, Mexico, during September 2004 and February 2005. Black points represent sampling stations.

$\mathrm{cm}$, and mouth perimeter of $68 \mathrm{~m}$; duration of hauls were about an hour at an average speed of $5 \mathrm{~km}$ per hour. Environmental variables, such as temperature and concentration of dissolved oxygen in the water column, were measured at each station with a CTD. A subsample of 20 $\mathrm{kg}$ was taken randomly and kept frozen until subsequent processing in the laboratory. Members of the family Moridae were separated and identified to species level using keys and descriptions by Fitch \& Barker (1972); Paulin (1995), and Robertson and Allen (2002). Laemonema verecundum differs from the other members of the family in the area for having a microscopic chin; it also has a row of vomerine teeth, and the pelvic fins are reduced to two rays; the belly is without spots and devoid of scales (Inada, 1995).
Voucher specimens were fixed in $10 \%$ formaldehyde and were subsequently preserved in $70 \%$ ethanol (Fig. 2). The material was deposited at the fish collection of the Laboratory of Fisheries of the Centro de Investigaciones Biológicas del Noroeste, Unidad Sonora, Guaymas campus.

Specimens of $L$. verecundum ranged in size from 75 to $247 \mathrm{~mm}$ total length (TL), with an average size of $157.5 \mathrm{~mm}$ TL, and a modal size of $150 \mathrm{~mm}$ TL. Females $(\mathrm{N}=226)$ ranged in size from 100 to $240 \mathrm{~mm}$ $\mathrm{TL}$ and males $(\mathrm{N}=80)$ from 70 to $200 \mathrm{~mm} \mathrm{TL}$, two folds greater than the maximum length reported by Paulin (1995); 324 specimens were immature (Fig. 3, Table 1).

Table1. Capture dates and geographical coordinates of Laemonema verecundum during the two research exploration cruises in the Gulf of California, Mexico. $\mathrm{O}_{2}=$ oxygen, $\mathrm{T}=$ temperature; material examined in number of organisms, and $\mathrm{TL}=$ total length.

\begin{tabular}{|c|c|c|c|c|c|c|c|}
\hline $\begin{array}{l}\text { Cruise } \\
\text { date }\end{array}$ & $\begin{array}{l}\text { Throws } \\
\text { number }\end{array}$ & $\begin{array}{l}\text { Latitude } \\
{ }^{\circ} \mathrm{N}\end{array}$ & $\begin{array}{l}\text { Longitude } \\
{ }^{\circ} \mathrm{W}\end{array}$ & $\begin{array}{l}\text { Depth } \\
(\mathrm{m})\end{array}$ & $\begin{array}{c}0_{2} \\
(\mathrm{mg} / \mathrm{l})\end{array}$ & $\begin{array}{c}\mathrm{T} \\
\left({ }^{\circ} \mathrm{C}\right)\end{array}$ & $\begin{array}{c}\text { Material } \\
\text { examined }\end{array}$ \\
\hline 01/09/2004 & 6 & $28^{\circ} 09^{\prime} 05^{\prime \prime}$ & $111^{\circ} 18^{\prime} 10^{\prime \prime}$ & 165 & 3.70 & 19.9 & 100 (TL 75-247 mm) \\
\hline 01/02/2005 & 3 & $25^{\circ} 40^{\prime} 12^{\prime \prime}$ & $109^{\circ} 35^{\prime} 21^{\prime \prime}$ & 483 & 0.29 & 9.5 & $1($ TL 160 mm) \\
\hline 09/01/2005 & 11 & $27^{\circ} 45^{\prime} 27^{\prime \prime}$ & $110^{\circ} 52^{\prime} 31^{\prime \prime}$ & 214 & 1.81 & 15.0 & 67 (TL 87-170 mm) \\
\hline $11 / 02 / 2005$ & 18 & $27^{\circ} 40^{\prime} 24^{\prime \prime}$ & $110^{\circ} 48^{\prime} 28^{\prime \prime}$ & 278 & 0.58 & 12.4 & 100 (TL 112-113 mm) \\
\hline $12 / 02 / 2005$ & 19 & $27^{\circ} 44^{\prime} 26^{\prime \prime}$ & $110^{\circ} 54^{\prime} 32^{\prime \prime}$ & 318 & 0.70 & 12.7 & 90 (TL 130-215 mm) \\
\hline 13/02/2005 & 20 & $27^{0} 54^{\prime} 32^{\prime \prime}$ & $111^{\circ} 08^{\prime} 04^{\prime \prime}$ & 198 & 2.14 & 14.4 & 21 (TL 124-175 mm) \\
\hline $13 / 02 / 2005$ & 21 & $27^{0} 51^{\prime} 30^{\prime \prime}$ & $111^{\circ} 12^{\prime} 07^{\prime \prime}$ & 285 & 0.47 & 12.0 & 100 (TL 115-182 mm) \\
\hline $12 / 02 / 2005$ & 22 & $27^{0} 59^{\prime} 35^{\prime \prime}$ & $111^{0} 18^{\prime} 18^{\prime \prime}$ & 289 & 6.91 & 18.1 & 100 (TL 113-190 mm) \\
\hline $14 / 02 / 2005$ & 27 & $27^{0} 22^{\prime} 13^{\prime \prime}$ & $111^{\circ} 06^{\prime} 06^{\prime \prime}$ & 245 & 0.92 & 11.5 & 69 (TL 111-240 mm) \\
\hline
\end{tabular}




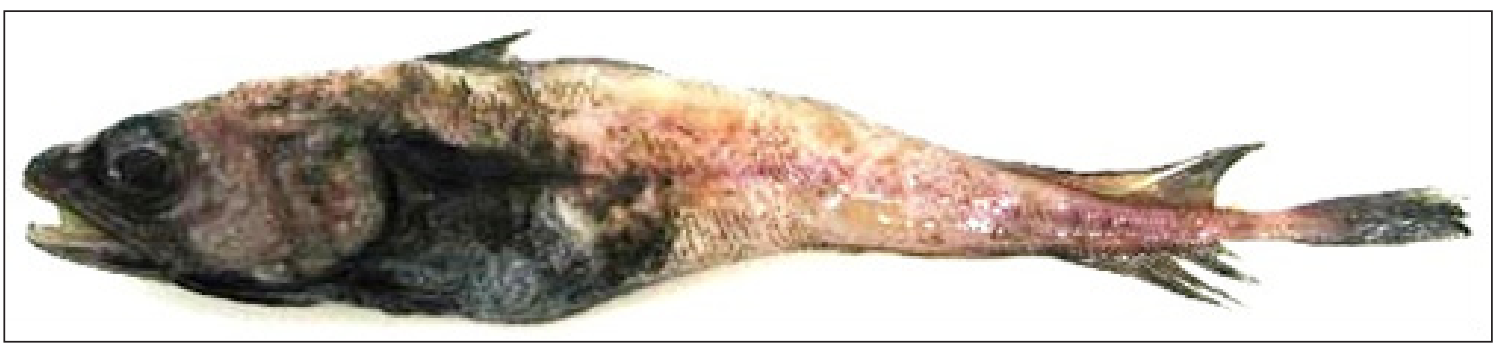

Figure 2. Specimen of Laemonema verecundum $(12.78 \mathrm{~cm})$ collected in the Gulf of California, Mexico, during September 2004 and February 2005.

Specimens of $L$. verecundum were collected at depths from 165 to $483 \mathrm{~m}$ and the greatest abundance was recorded at $280 \mathrm{~m}$. Temperatu$\mathrm{re} \leq 18^{\circ} \mathrm{C}$ and salinity $\leq 35.0$ were recorded at these depths, which are characteristic of the subtropical subsurface water mass (Torres-Orozco, 1993). The distribution of organisms was not homogeneous bathymetrically; $60 \%$ of the total catch was at a depth range from 260 to $300 \mathrm{~m}$ (Fig. 4), which was lower than zero reported by Bogutskaya (2007) by a difference of $500 \mathrm{~m}$. The catch area of the organisms went from $25^{\circ}$ $40^{\prime} 12^{\prime \prime} \mathrm{N}$ and $109^{\circ} 35^{\prime} 21^{\prime \prime} \mathrm{W}$ up to $28^{\circ} 09^{\prime} 05^{\prime \prime} \mathrm{N}$ and $111^{\circ} 18^{\prime} 10^{\prime \prime} \mathrm{W}$, based on nine stations where the species was present. The maximum catch was located between $27^{\circ} 22^{\prime}$ and $27^{\circ} 59^{\prime} \mathrm{N}$ south of Guaymas, Sonora (Table 1). Temperature and dissolved oxygen fluctuated at these stations from 9.5 to $18.1^{\circ} \mathrm{C}$, with an average of $13.1^{\circ} \mathrm{C}$, and from 0.29 to $6.9 \mathrm{mg} / \mathrm{l}$, with an average of $1.7 \mathrm{mg} / \mathrm{l}$, respectively.

The minimum catch was obtained at greater depths where temperature and dissolved oxygen were at a minimum level, $9.5^{\circ} \mathrm{C}$ and $0.29 \mathrm{mg} / \mathrm{l}$ (Table 1). The population structure of $L$. verecundum showed a high presence of young and adult organisms, which suggests that this species might be established in shallower waters (a still deeper continental shelf) of the Gulf. This type of distribution changes in reports of various marine species has been attributed to the effects of global climate change. However, the presence of this species in adjacent shallower waters suggests an expansion of its distribution.

This new record of $L$. verecundum reveals the distribution and size of its population in shallower waters, contributing to the understanding of the biology and ecology of a relatively poorly known deep-sea species of the Gulf of California.

\section{ACKNOWLEDGEMENTS}

The authors acknowledge that this research was part of a SAGARPACONACYT-2003 00-024 grant and the EP from the CIBNOR project. We wish to thank CIBNOR staff Eloisa Herrera Valdivia from the Laboratory of Fisheries at the CIBNOR Sonora Unit, Guaymas Campus and Diana Dorantes at CIBNOR La Paz for English editorial services.

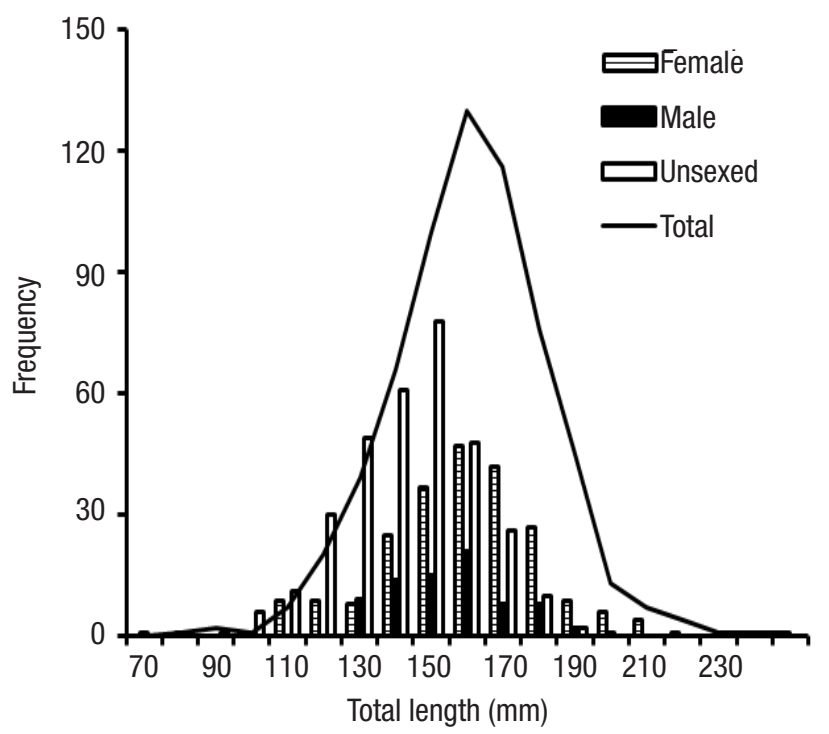

Figure 3. Size frequency by sex of Laemonema verecundum during the exploration cruises in the Gulf of California, Mexico, in September 2004 and February 2005.

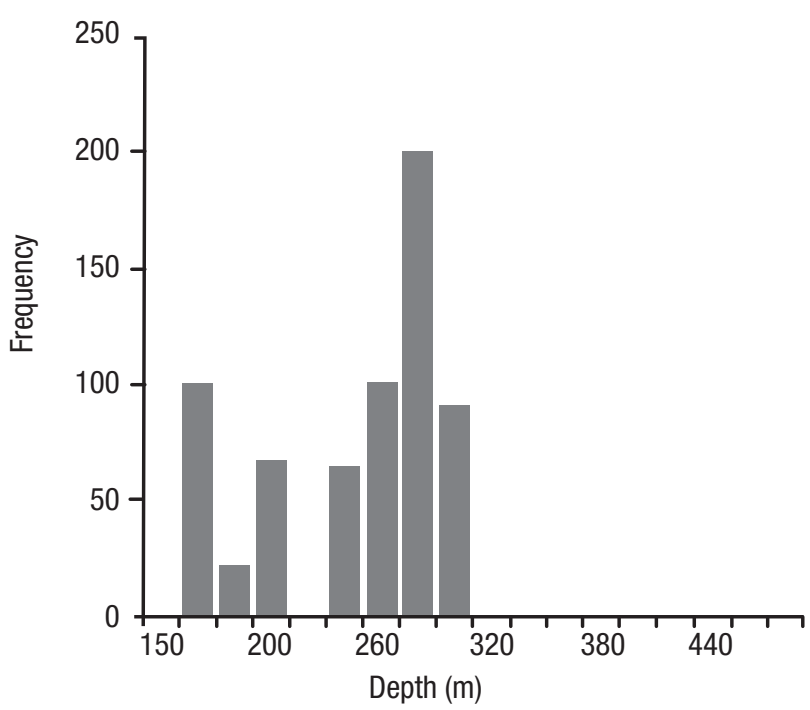

Figure 4. Organisms per hour of throws of Laemonema verecundum by depth during the exploration cruises in the Gulf of California, Mexico, in September 2004 and February 2005. 


\section{REFERENCES}

AlLeN, M. J. 2008. Bathymetric responses in functional structure of southern California demersal fish communities to Pacific Decadal Oscillation regimes and an El Niño. Southern California coastal water research project report 2008. Westminster, California, pp. 211-228.

Ambrose, D. A. 1996. Moridae: codlings. p. 500-507. In: H.G. Moser (Ed.). The early stages of fishes in the California Current region. California Cooperative Oceanic Fisheries Investigations (CalCOFI) Atlas No. 33. 1505.

Bogutskaya, N. G. 2007. Preliminary assignment of coordinates to type localities in the Catalog of Fishes. Unpublished dbf file.

Castro-Aguirre J. L. \& E. F. Balart. 1996. Contribución al conocimiento del origen y las relaciones de la ictiofauna de aguas profundas del Golfo de California, México. Hidrobiológica 6: 67-76.

Fitch, J. E., \& BARKER, L. W. 1972. The fish family Moridae in the eastern North Pacific with notes on morid otoliths, caudal skeletons, and the fossil record. Fishery bulletin 70 (3): 565-584.

HendRICKX, M. E. 2001. Occurrence of a continental slope deepwater decapod crustacean community along the edge of the minimum oxygen zone in the southeastern Gulf of California, México. Belgian Journal of Zoology 131: 71-86.

InADA, T. 1995. Merlucciidae. Merluzas. In: W. Fischer, F. Krupp, W. Schneider, C. Sommer, K. E. Carpenter and V. Niem (Eds.).Guía FAO para Identificación de especies para los fines de la Pesca. Pacífico Centro-Oriental. 3 Vols. FA0, Rome. pp. 1272-1274.

López-Martínez J., A. Acevedo-Cervantes, E. Herrera-Valdivia, J. RodriguezRomero\& D. S. Palacios-Salgado. 2012. Composición taxonómica y aspectos zoogeográficos de peces de profundidad $(90-540 \mathrm{~m})$ del Golfo de California, México. Biología Tropical 60 (1): 347-360.

Robertson D. R. \& G. R. AlLen. 2002. Shore fishes of the tropical Eastern Pacific; an Information System. CD-ROM. Smithsonian Tropical Research Institute, Balboa, Panamá.

Paulin, C. 1995. Moridae. Moras, Molleras, Carboneros. In: W. Fischer, F. Krupp, W. Schneider, C. Sommer, K.E. Carpenter and V. Niem (Eds.). Guía FAO para Identificación de Especies para los fines de la Pesca. Pacifico Centro-Oriental. 3 Vols. FA0, Rome. pp. 1281-1288.

Torres-Orozco, R. E.1993. Análisis volumétrico de las masas de agua del Golfo de California. Tesis de maestría, CICESE, Ensenada, Baja California, México 80 p. 